\title{
トルクコンパータと流体継手の作用と
}

棈造についで

\section{1. 䋛留}

流体継手（fluid coupling）抽よびトルク コンパ夕 (torque converter) はともに令世紀の初期澄明 され、ここ10数年の間に各種用途に急激な発展をとけ゚た 動力伀達装圆である．流体を媒体として動力を伀える方 法には，容積型の油ポンプと油モータを組合せた静水力 的なもの（液圧伝動装置）と,ターボ式のポンプとター ビンを組合せた動水力的なるのとがある。ここに述べる 流体継手やトルクコンバー夕後者の組合せであって, 前者に比べて比較的大签量の動力を簡単に坛達でさるこ とや，可撓性をひっていること等が特長となっている， なお前者は主として負荷の変動によらず任意の変速比に 保つことを目的としているのに対し，後者は主として負 荷の変動に応してある傾向のもとに变速比が自動的に变 わることを目的としている。

\section{2. 流体継手の作用}

流体継手は一般に直線放射状の羽根をもっだポンプ羽 根車とタービン羽根車とを向い合せに組合せて内部に油 を満したもので，第 1 图はその回転軸を含を平面におけ る断面罒である. 入力軸そ出力軸の回転差によって生じ

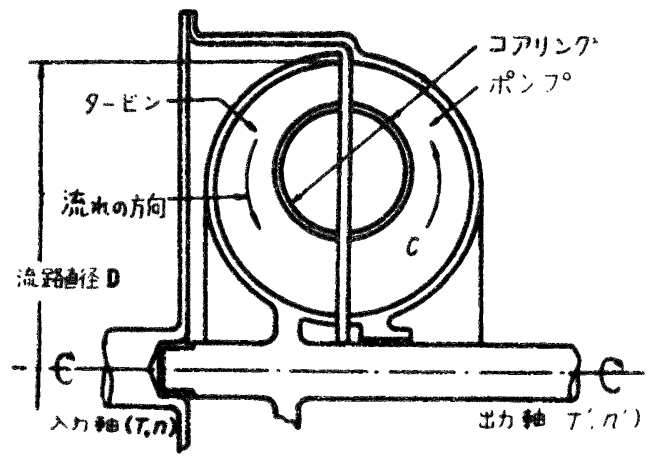

（第1図）流体継手断面
石原智男 ${ }^{4 *}$

る币カ差のために，油は四の矢印の方向飞流れて循環 し，その際の角運動量の交換によってトルクを伝澾す る、ポンプが油に与える角運動量の变化を受けるのはタ 一ビンだけであるから，入力軸トルクは本質的に出力軸 トルクに等しい、入力軸回転速度に対して山力軸回転速 度が低い浮ど圧力差が大となって循環油量が增し，それ につれて伝達トルクが增大する。な拈正規の運転状態で は，出力軸が入力軸より速く回転することはない。したか゚ って流体継手はなめらかなすべりを許す一種のクラッチ である. 入力軸回転速度を $n$ (r.p.m.), 壮力軸回転速度 を $n^{\prime}$ (r.p.m.), 伀達トルクを $T(\mathrm{~m} \mathrm{~kg})$, 循環流速を $c$ $(\mathrm{m} / \mathrm{s})$, 流路直径を $D(\mathrm{~m})$ とすれば， $c$ は $n D$ に比例 し, 循璒油量は $n D^{3}$ に此例する。トルクは循環油量と 流速と直径との槛に比例するので， $T \propto n^{2} D^{5}$ となる.

これらの比例係数は流路の形状, 油の性質, 两軸回転速 度の比すなわち速度比 $e=n^{\prime} / n$ によって変化する，第 2 図は相似形の流休継手の性能例を示したるので，効㳯は

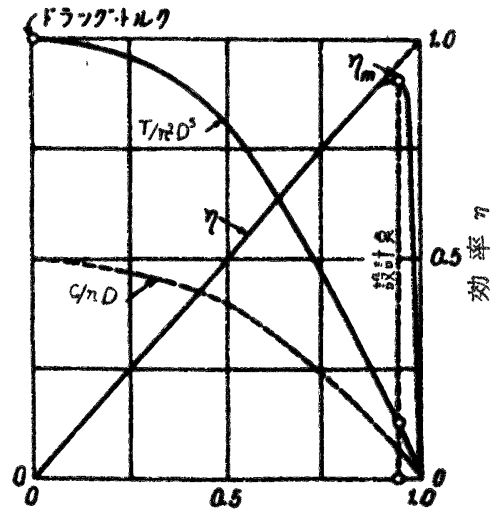

（第 2 汹）流体継手の性能

$\eta=T n^{\prime} / T n=e$ により直線的になる，效率の点からみて 速度比が 1 に近いところ（普通は $e=0.95 \sim 0.98$ 程度） を設計点にするように流体継手の大きさを定めることが

* Principle and Constructions of Torque-Converters.

** T. Ishihara, Member。東京大学生锖技術研究所 


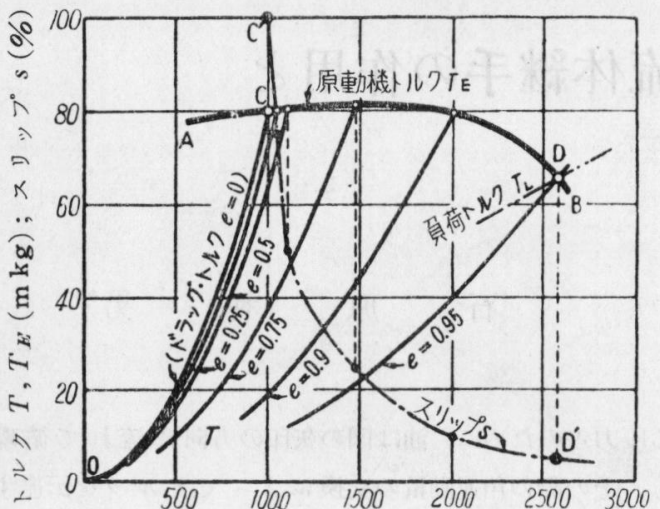

原動機回転速度 $n$ (r.p.m.)

（第 3 図）原動機之流体継手の組合せの例

望ましい, 第 3 図はこの流体継手を特定の原動機につけ た場合の性能で，図中のスリップは $s=(1-e) \times 100 \%$ を表わす. 図より出力軸停止 $(e=0)$ に拉ける伝達トル クの值ができるだけ小さいことが望ましい。このトルク をドラッグトルクとよぶ. 常用運転範囲で原動機の性 能と流体継手の性能とを合理的に合わせることが望まし いのでこのような籁用で成立する性能計算式が用いら れている.すなわち $S<10 \%$ に対して近似的に

$$
N_{1}=c_{8}(n / 100)^{3} D^{5}
$$

ここに $N_{1}=$ 入力軸馬力 $(\mathbb{P}), c$ は流路形状や油の性質 拈よび場合によっては挿入油量によって変化する係数で ある、第 4 図はその数值例を示す。

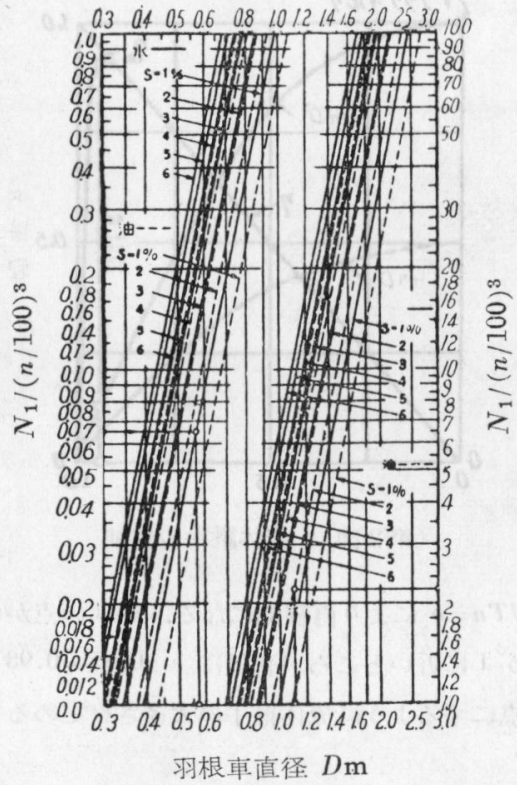

（第 4図）流体継手設計表の例

\section{3. 一定充てん式流体継手}

流体継手には, 回路内の油を運転中に人為的に出し入 れするものとしないものとがある，一定充てん式は後者 であって,この場合には設計点の伝達トルク容量を下け゚ ることなくドラッグトルクを小さくする工夫が必要で ある、し゚やま板，貯油槽，環状弁，特殊回路形状等がこ の目的のために用いられる、第 5 図はじやま板と貯油槽 をつけた例，第6 図は環状弁をつけた例，第 7 図は特殊 流路形状の例である。一般にこのような流体継手の充て

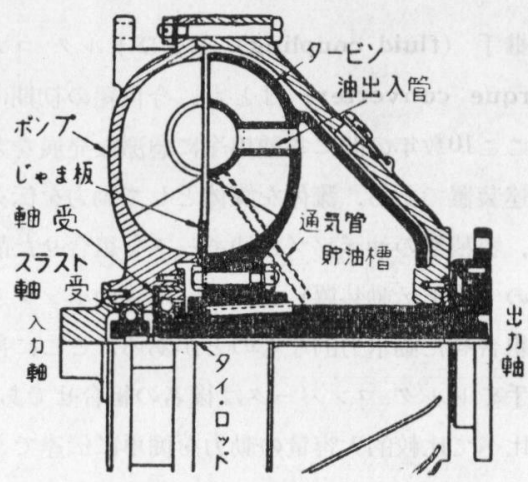

（第5 図）じやま板，貯油槽付流体継手

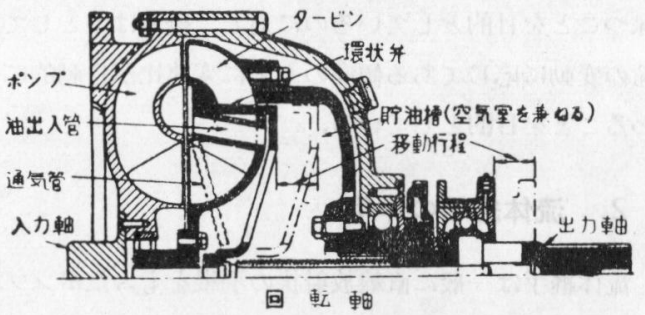

（第6図）貯油槽，環状弁付流体継手

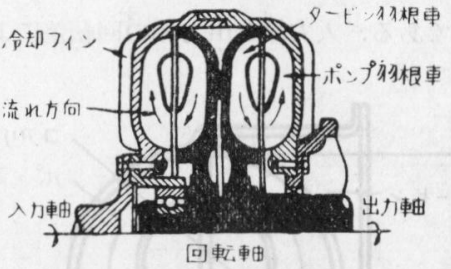

（第7困）双子型流体継手

ん油量は回路に一部空気が残る程度に定めるのが普通で ある.スリップの小さい状態では循環流は外周に片寄 り，じやま板は作用しないが，スリップが大さくなると 循環流が内側にも流れてじやま板の抵抗を受け，それに よってドラッグトルクが低下する．貯油槽は流路内で 作動する油量をスリップに応じて自動的に加減する作用 をなし，100ッスリップ付近では流路内にごくわずかの 


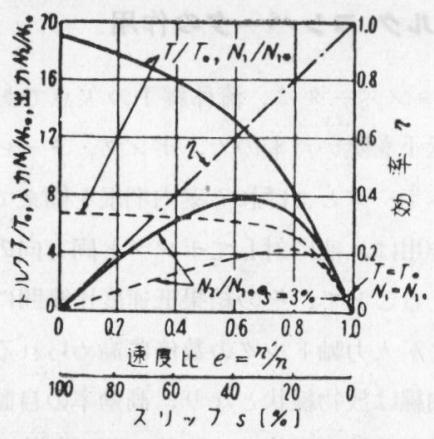

（第 8 図）貯 油槽の影響

——貯油槽なし $\}$ 貯油槽あり $\}=3 \%$ トルクは同一

$T=ト ル ク, T_{*}$ *スリップ $3 \%$ に和けるトルク

$N_{1}=$ 入力, $N_{1 \%}=$ スップ $3 \%$ K拈ける入力

$N_{2}=$ 出力 (いずれも $n=$ 一定の場合)

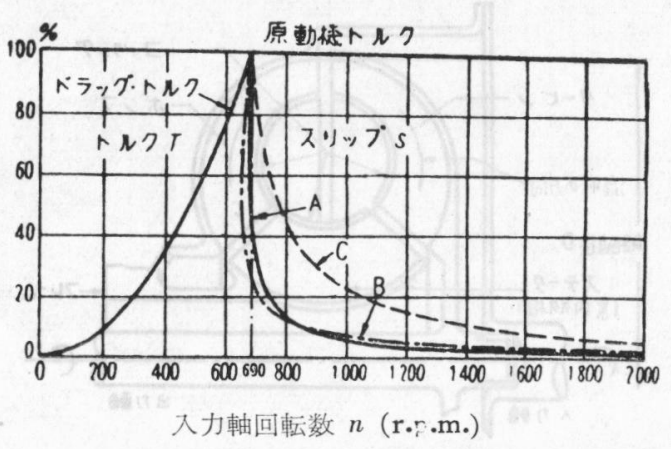

（第9図）スリップ曲線の比較

(ドラッグトルクが等しくなるように設計；

$D_{A}>D_{B}>D_{C}$ となる)

\begin{tabular}{c|c|c} 
& 貯 油 槽 & じゃま板 \\
\hline$A$ & 大 & 有 \\
\hline$B$ & 中 & 無 \\
\hline$C$ & 小 & 無
\end{tabular}

油しか残畄しないので、ドラッグトルクがきわめて小 さくなる，環状弁は流れを絞ることによってドラッグ

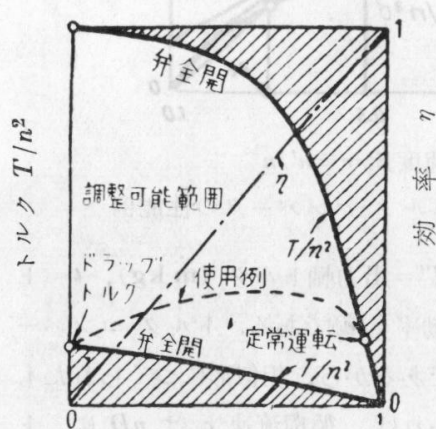

速度比 $e=n^{\prime} / n$

(第 10 図)

環状弁付流体継手の性能
トルクを下げるも ので, その作動は 外部から人為的に 扰こな5。環状升 付流体継手はその 弁の適当なる操作 によって一種の変 速機になりうる。 第 $8,9,10$ 図は これら補助機構の 効果を示す.

\section{4. 可変充てん式流体継手}

流体継手によって任意の変速作用をさせることは，環 状弁付以外の一定充てん式のるのでは不可能である. 環 状升付でもその变速範囲には限度があるので，広範囲の 連続的な变速作用をさせるためには, 外部から回路内の 作動油の量を調節してやる必要がある、このような装置 をつけたものを可変充てん式流体継手とよら゙. 第 11 図

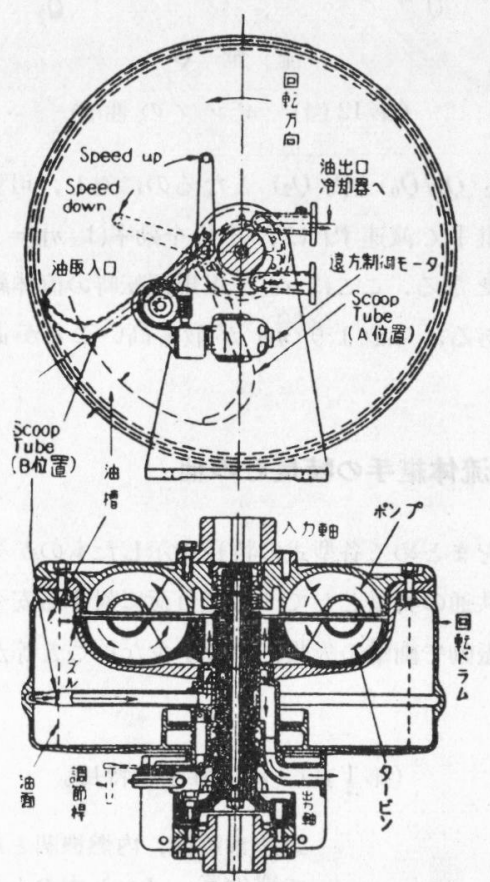

（第11戝）可变充てん式流体継手

はその一例である. 油量の調節には, スクープチュー ブを用いるものと, 別に備えたポンプによるものとがあ る.油を空の状態にすれば伝達トルクはほとんど 0 とな りスリップは $100 \%$ ス近くなる. 油を一杯にすれば， 全力でトルク伝達をおこならのでスリップはほとんど0 になる、ただ流体継手の本質として，どのようなスリッ プ状態でも入力軸と出力軸のトルクが等しいので，スリ ップの増加につれて効率が低下することは避けられな い,しかし, 例えばポンプ, 送風機等を定速電動機で運 転し、その流量を広範囲に調節しなければならないよ5 な場合には, 流体継手を使用して変速させる力が絞り弁 やバイパス弁による流量調節よりはるかに経済的であ る. 第 12 図の定速電動機駆動ポンプ系で, 回路抵抗が $H=K Q^{2}$ で与えられるとき，正規流量 $Q_{0}$ から $Q_{1}$ に 変化させる場合, 絞り弁によるときの全効率は $\eta \mathrm{I}=\boldsymbol{\eta}_{h 1}$ $\left(Q_{1} / Q_{0}\right)^{2}\left(H_{0} / H_{1}\right)$ ，バイパス升によるときの 全効率は 


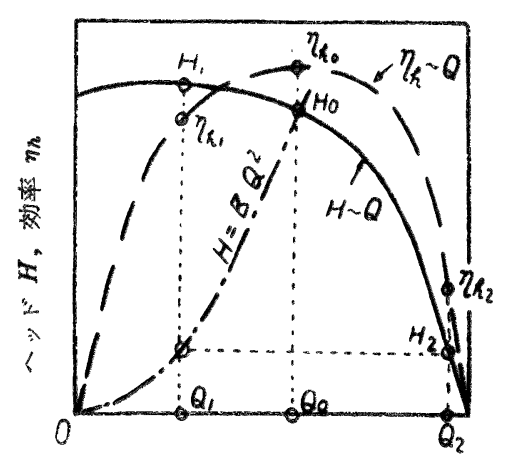

流 畐 $Q$

（第 12困）ポンプの性能

$\eta_{\mathrm{II}}=\eta_{h 2}\left(Q_{1} / Q_{0}\right)\left(Q_{0} Q_{2}\right)$ となるのに対し, 可変充てん

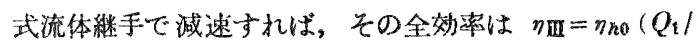
$\left.Q_{0}\right) e_{0}$ となる。ここに $e_{0}$ は正規運転時の流体継手の速 度比である。これより る.

\section{5. 流体継手の特舆その他}

以上をまとめて各型式の特長を示したすのが第 1表で ある。共通の特長としては, 過負荷に対する安全作用, ねじり掓動や衝撃の吸收, 故障が少ないこと等が挙げら れる。

（第 1表）流体継手の特畏

\begin{tabular}{|c|c|}
\hline $\begin{array}{l}\text { 一定充てん式 } \\
\text { (じゃま板，眝油 } \\
\text { 槽付を含し） }\end{array}$ & $\begin{array}{l}\text { 定速需動機, 内燃機関と組合せ } \\
\text { て惯性モーメント大のるのの起 } \\
\text { 動に便利 } \\
\text { ストール性能の利用がでをる } \\
\text { 機関の全力起動がでさて加速が } \\
\text { よい }\end{array}$ \\
\hline 環 状弁 付 & $\begin{array}{l}\text { ある程度の藺速が可能. 急激に } \\
\text { 負荷をかけられる。ドラッグ } \\
\text { トルクを下げて起動を容易にし } \\
\text { エンシンストップをなくする }\end{array}$ \\
\hline 可変充てん式 & $\begin{array}{l}\text { 定速電動機による無䝿荷起動が } \\
\text { 可能·連続広範囲の調速が可能 }\end{array}$ \\
\hline
\end{tabular}

流体継手の動力損失に基く発熱は作動油の温度上:界と なって晛われるので，何らかの冷却を必要とする。一般 に適当な鉱物油が使用されるので, 油温上界の限界は普 通の油で大体 $80^{\circ} \mathrm{C}$, 特殊の油で大体 $130^{\circ} \mathrm{C}$ である。

一定充てん式は一般にスリップの小さいところで常用運 転されるので，油温の上昇はあまり問題とならず，外面 の空冷で間に合うことが多い。

\section{6. トルタ コンバータの作用}

トルクコンパータは，流体継手の欠点である低速度 比の効率低下を除いたもので，ポンブ，タービン羽根車 のほかにステータとよばれる案内羽根を嚅えている。大 テータの作用は，油に対してポンブと戌方向の角造動量 变化を与えることで，その結果低速度比範果に和忛る出 カ軸トルクが入力韩トルクの数倍に高められる。したが ，て效率曲線は放物線状となり，高效率の自動变速装置 となる。効率曲線の形状は，流路の断面形状，羽根車の 配筫, 羽根の曲り具合等によって大巾に変化する。この 点が流体継手と全く異なる点であって，その合理的な設 啩には豊富な資料を必要とする。第 $13 ， 14$ 因は最も簡 単な棈造のものの断面図と性能例を示す. 図中 $\boldsymbol{T}=$ 入力

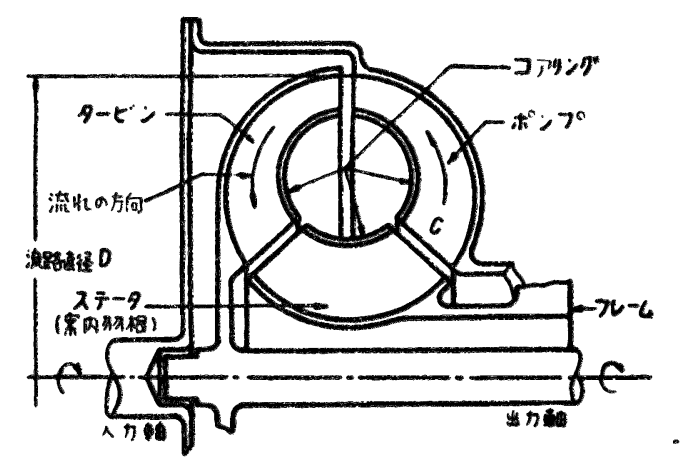

（第13図）1段トルクコンバータ断面

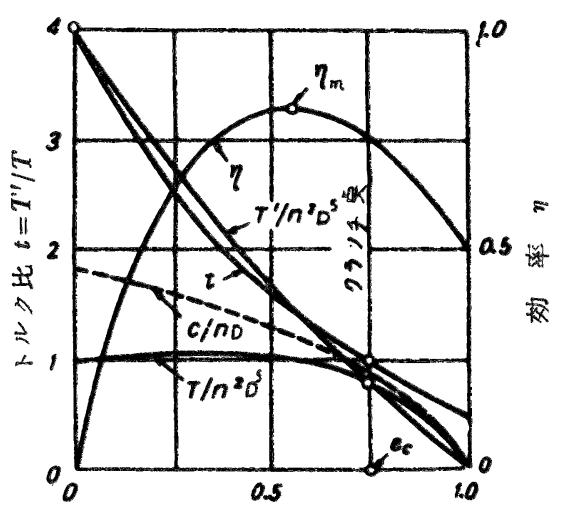

速度比 $e=n^{\prime} / n$

(第 14、困) トルクコンバータの性能例

軸トルク $(\mathrm{m} \mathrm{kg}) 、 T^{\prime}=$ 出力韩トルク $(\mathrm{m} \mathrm{kg}), t=$ ト ルク比 $=T^{\prime} / T, \eta=$ 效率=teである。トルクコンパー 夕む動水力的なものであるから，相似形につくられたも ので作動油が類似であれば，循環流速 $c$ は $n D$ K, ト ルク $T, T^{\prime}$ は $n^{2} D^{5}$ 比例する. その比例係数は速度 此 $e$ の関数となる。因上りわかるよ 5 に。るる速度比 
範井にわたってトルク コンバータの入力軸トルク $T$ は 比較的変化が少なく, 出力軸トルク $T^{\prime}$ が速度比の減少 とともに増大する。すなわち広範囲の運転条件に対して 原動機の最大出力が使用でき，しか子負荷に応じて全く 自動的に変速が打こなわれることになる、なおトルク コンパータの各羽根要素は常に有效に働かねばならない ので，油は流路を完全に満した状態で使用される.

\section{7. トルクコンバータの段数とトルク比}

トルクコンパータの性能を高めるといらことは, 全 範井のトルク比をできるだけ高め，しかる入力軸トルク 曲線の形状と最高効率の生じる速度比の位置とが適当に 保たれるようにすることである.一般的な傾向として， 速度比 0 の点（ストール点とよぶ）のトルク比すなわら ストールトルク比（最大トルク比） $t_{s}$ の值を大きくし よ5とすると, 最高効率 $\eta_{m}$ がど いまをた $t_{s}$ を極端に大にすると入力軸トルク曲線の形 が不適当になることが多い、例えば第 13 図の形式では 最高効率を下け゚ずに $t_{s}$ を 4 以上にすることは容易でな く，入力軸トルク曲線から考えても，現状では大体のと ころ $t_{s}=4$ で $\eta_{m}=80 \%, t_{s}=2 \sim 3$ で $\eta_{m}=90 \sim 85 \%$ 程度である. 效率を下け゚ずに $t_{8}$ をこれ以上高くするた めやまた入力軸トルク曲線を速度比によらずほとんぞ

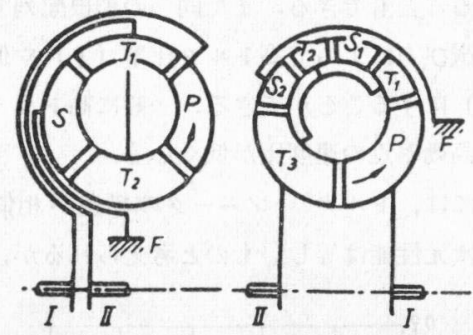

2 段型（4要素） 3 段型（6要素）

(第 15 図) 多段トルクコンバータの断面模型図

$P=$ ポンプ, $T=$ ターピン,$S=$ ステータ

$F=$ フレーム, $\mathbf{I}=$ 入力軸, $\mathbb{I}=$ 出力軸

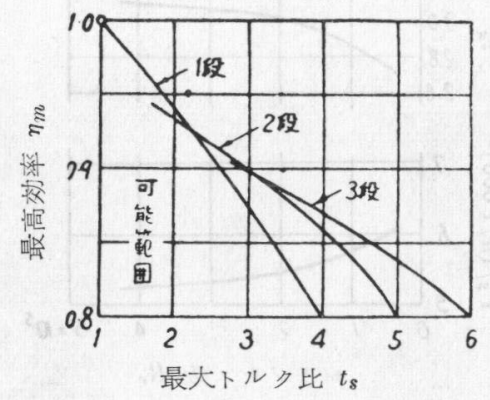

（第16図）性能限界線:
一定にするためには，特殊構造にするかまたはタービ ン羽根車を分割して多段型式にしなければならない、第 15 図は $2 ， 3$ 段の羽根車の配列を示したもので，第 16 図は段数を増すことによって最大トルク比を大きくとる ことのできる有様を示したものである.な持特殊構造の ものや，入力軸トルク曲線の形状を問題にしないものに は,この性能限界を越すものもある.

\section{8. トルタ コンバータ性能改善のための補助 機構}

トルクコンパータの効率曲線は第14罒に示すよ5に 一般に放物線状をなしている.とこで最高效率の速度比 付近たけを使用するような場合を除けば，一般に最高効 率点前後の教率の低下は望ましくない，速度比の小さい 範井の効率の低下はトルクコンバータとして本質的に 避けられないものであり，しかもその範囲は主として過 負荷または起動時に使われるので,トルク比が必要とさ れる值以上であればそれほど問題とならない、これに反 して速度比の大きい範囲での効率の低下は, その範囲が 一般に常用運転の領域となることが多いので致命的な問 題となる. そこで起動時および加速時にトルク コン： 一タのもつなめらかなトルク裹換の利点を生かし, 常用 運転時には効率の良い機械式直結かまたは流体継手伝動 に切替えることが和こなわれている，その切替点として はトルク比が $t=1$ になる速度比を選ら゙のが最も合理的 である.この点をクラッチ点とよら゙. 多段型にはこの直 結装置を備えたものが多い、第 17 四は直結装置扣よび

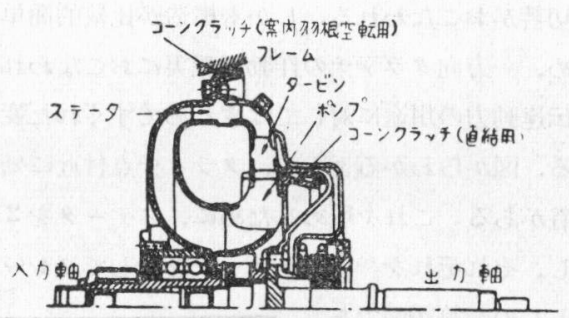

（第17汹）直結装膡付

Borgward トルクコンバータ.

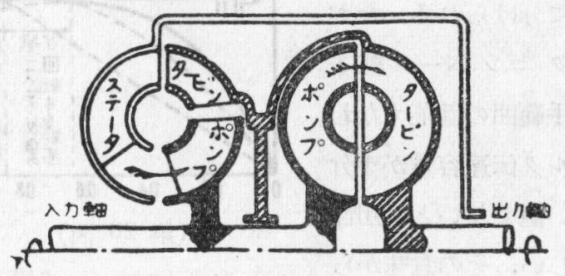

（第 18 脳） Voith 式流体变速装固 


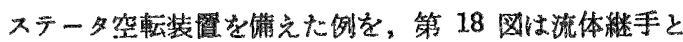
の組合せの例を示す。第 18 図の方法は, クラッチ点以 下の速度比では流体継手の油を空にし，クラッチ点以上 の速度比ではトルク コンバータの油を空にする.この カ式のものは棈造が複㧼で高洒になるので，大容量の特 別な用透にだ用いられる。

\section{9. トルタ コンパー夕継手}

速度此がクラッチ点以上になると性能が低下する原因 はステータにある、ステータが受持つトルクは出力軸ト ルクと入力軸トルクとの差に等しい，したがって，クラ $y$ 点以上の速度比では $t<1$ となりステータは全く無 效な負のトルクを受持っていることになる。クラッチ点 を境にしてステータに作用するトルクの向きが変化する ことを利用し，クラッチ点以下ではステータが固定さ れクラッチ点以上ではステータが空転するようにして やれば,第 18 図の場合と同様な性能が容易にえられる。

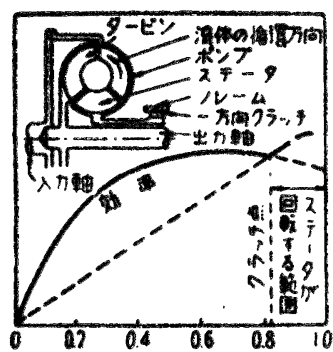

(第 19 国)

トルクコンバータ継手

(2 相)

それには第 19 罒のよう にステータとフレームの 間に一方向にしか回転で きないクラッチ(一方向 クラッタ）を設けてやれ ばよい。これがトルク コンパータ継手であっ て,クラッチ点で自動的 にしかも衝撃なしにトル クコンパータ $\leftrightarrows$ 流体継

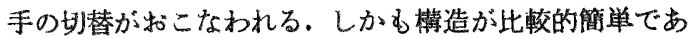
るため，一方向クラッチの作動が確実に特こなわれる程 度の公達動力の用途に対してはきわめてすぐれた変速機 となる。四からわかるように，クラッチ点付近に効率曲 線の谷がある、これを埋めるために，ステータを2個に 分割し，それぞれを一方向クラッチを介してフレームに 結合したのが第20罒であ る.これによって全速度 比が 3 俑の異なった性能 範围に分けられる。な战 トルクコンバータ継手 の継手範用の性能すなわ らトルク会達产量が十分 に简い做でないと実用性 にそしい、その意味から トルクコンパータ継手

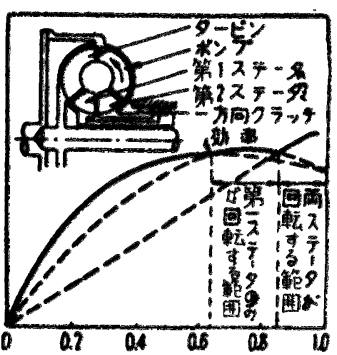

(第 20 図) トルクコンバータ継拜 (3 相)
にでさる羽根配列には制限がありどのようなトルク コンパータであトルクコンパー夕継手になるとは限ら ない.

\section{0.トルクコンバータの性能におよぼす諸 影留}

トルクコンバータの性能は羽根車の配列や羽根角度 の变化によって大巾に变化する、第21図に示すように，
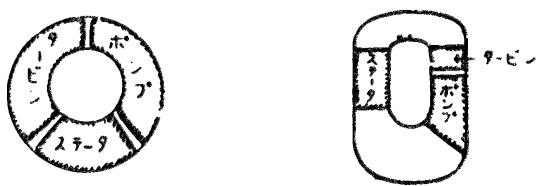

$4 \cdot(\bar{a})-$
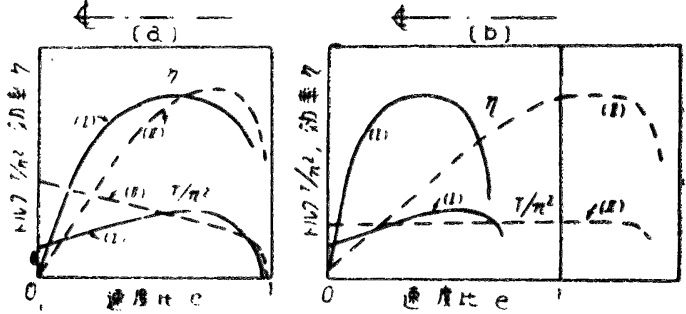

（第21図）トルクコンバータの型式と性能

(a) の羽根配列のものでは一般にその最高速度比は $e=1$ で括さえられるが，(b) の羽根配列にすると羽根 角度の組合せによって最高速度比を $e<1, e>1$ のい ずれにすることるできる。李た同一の羽根配列です，羽 根角度の選び方によって高トルク比型（I）や低トルク 比型（【）にすることができる。一般に高トルク比型の ものは最高効率点の速度比が低くなる。

近似的には,トルクコンパータの權造が相似であれ ばその無次元性能は等しいものと考えられるが, 笡密に
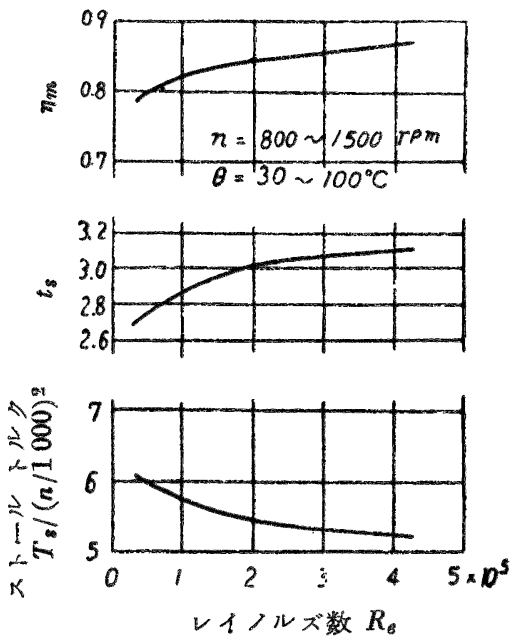

（第 22困）レイノルズ数の影睯 
考えれば，大きさ， 使用回転速度, 油 の種類, 油温等の 相違炕よって多少 変化するものであ る.大きさが極端 に違壳ば，小型の ものほど性能低下 が避けられない が，その相違の大 部分は機械効率の 影響であって，水 力的な相違はそれ 程でもない，機珹 効率の变化を除い て考えれば，性能 変化は流れのレイ ノルズ数扣よび羽 根表面の相対粗度 によって規定され る. 特比翼型使用
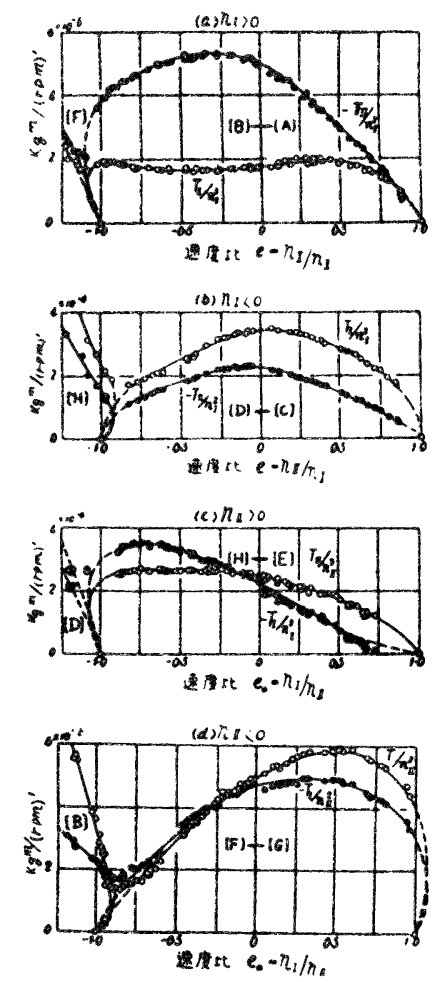

(第 23 困)

のトルクコン:

1段トルクコンバータの完全性能

一タでは後者の影響が此較的大きく表われる、レイノル ズ数の影響は，例えば第 22 四に示すような程度であっ て, ある程度以上のレイノルズ数では性能変化は小さく なる.ここにレイノルズ数は $R_{e}=c D / \nu$ にって定㼁 される. $c=$ 循環流速， $D=$ ポンプ值径， $\nu=$ 油の使用温 度に拉讨る動粘性係数。

\section{1. トルク コンバータの特殊荛転性能その他}

トルクコンバータとれ自体には可逆性がない。逆方 向に回転させた場合には正転時と全く違った性能になる ことを注意せねばならない，第 23 因は第 13 図の1段卜 ルクコンバータの完全特性を示したもので, 図中 $n_{I}=$ ポンプ回転速度， $n_{\mathrm{II}}=$ タービン回転速度， $T_{\mathrm{I}}=$ ポンプ 軸トルク， $T_{\mathrm{II}}=$ タービン軸トルクを示す， $n_{\mathrm{I}}, n_{\mathrm{II}}>0$ が正規運転範畔である。

トルクコンバータの流路内は常に油がー杯に満され ている必要があり、これに気泡が混入したり，過熱によ って蒸気が発生したりすると，性能低下をるたらす。と のため外部から油を加圧する必要がある，筆者の実験に よれば、トルクコンバータ内の最低圧力部に叔るる油 の比重量が気泡を含まない油の此重量の $3 \%$ 減程度にな るまでは多少気泡が混入しても差しつかえないようであ る、したがって不必要な高い圷力での加压は無意味であ る. 現在では大体 $3 \mathrm{~kg} / \mathrm{cm}^{2}$ 以下である.

\section{2. 苗車変速装置との組合せと応用例}

流体継手怙よびトルク コンバータ単体ではその性能 が不満足の場合，これに補助の崡本変速装置を付加寸る ことが怙こなわれている，特に車両用としては，最近各 種の補助霜車装置が考案され，自動運転の効果を発揮し ている、流体継手扰よびトルク コンバータの俧用とし ては, 自動車，鉄道用ディ一ゼル機関車，同動車，垍㭊 機珹，運搬機械，荷役機械，巨延伸線機，流体機械等の 広範围にわたって和り，その伝達馬力も数 $\mathbb{P} か ら 1000$ 闸上に扮よんでいる。 